\title{
As a Warning to Others or Do the Same?--A Study on the Spillover Effect of Punishment against Interlocking Company
}

Xiangge Meng ( $\nabla$ xianggem5@gmail.com )

Harbin Commercial University: Harbin University of Commerce

\section{Research Article}

Keywords: punishment, interlocking directors, spillover effect, accounting information comparability

Posted Date: October 25th, 2021

DOl: https://doi.org/10.21203/rs.3.rs-998417/v1

License: (c) (i) This work is licensed under a Creative Commons Attribution 4.0 International License.

Read Full License 


\title{
As a Warning to Others or Do the Same? - A Study on the Spillover Effect of Punishment against Interlocking Company
}

\author{
Xiangge Meng *, Yang Lu \\ School of Accountancy, Harbin University of Commerce, Harbin, China \\ *Correspondence Author: Xiangge Meng,
}

\begin{abstract}
Based on the theory of organizational penalty spillover, this paper discusses whether the punishment against interlocking company will affect the accounting information quality of the observing company through the channel of interlocking directors. The research results show that the observing company significantly improves the accounting information comparability within two years after interlocking company is punished when compared horizontally with an interlocking company that is not punished. The observing company also significantly improve the accounting information comparability within two years after the interlocking company is punished when compared longitudinally with before an interlocking company is punished. The findings show that the punishment against listed companies by CSRC and other regulatory authorities have spillover effect, the punishment is not only an act of correcting deviations after the event, but also an attempt to improve the accounting information quality of unpunished companies by punishment that is a Warning to Others.
\end{abstract}

Keywords: punishment; interlocking directors; spillover effect; accounting information comparability

\section{Introduction}

In recent years, capital market regulatory authorities pay more and more attention to the supervision of illegal behavior of listed companies. In 2019, a total of 296 punishment decisions have been received, with a cumulative punishment amount of 41.83 billion yuan. If a listed company is punished, it will have a significant negative market response to the punished company ${ }^{[1-4]}$.The organizational behavior theory holds that organizational punishment has spillover effect, and Trevino (1992) ${ }^{[5]}$ finds that punishment was a kind of social event, and punishment would not only have an impact on the punished one, but also affect the other unpunished organizations or individuals associated with the punished company. The purpose of the organization punishment is not limited to the punishment, and the spillover effect of punishment is also to be paid attention to. The previous studies show that the spillover effect of punishment has not only a contagious spillover effect on other issues ${ }^{[6-9]}[10-15]$

Companies with interlocking directors accounted for more than $84 \%$ of all listed companies in 2008 and 90\% in 2019 in China, indicating that the phenomenon of interlocking directors of listed companies in China is already very common, and listed companies have formed a network based on the interlocking directors. With the popularity of the phenomenon of interlocking directors, more and more literatures find interlocking directors can help companies to achieve information transmission ${ }^{[16-19]}$ and produce behavioral convergence ${ }^{[20-25]}$. A As the observing company and the interlocking company have a common director and the interlocking company has been punished, the investor is likely to pay attention to the unpunished observing company. In order to reduce the negative sentiment of the investors, the observing company will take positive action to emphasize its own advantages and maintain its image.

As a "quality-enhancing feature", accounting information comparability can reflect the company's financial situation, operating results and cash flow more profoundly, and provide more comprehensive source of information for investors. Accounting information comparability is difficult to manipulate through the company's own accounting policies and methods, so it is difficult to imitate. Therefore, according to Spence (2002) ${ }^{[26]}$ signal theory, the observing company may adopt the appropriate signal to improve the accounting information comparability that transmits information. In addition, the interlocking directors will transfer the experience and corrective actions accumulated in the punishments to the observing company, so as to improve the governance level of the observing company and the accounting information comparability of the observing company.

China has disclosed the punishments against listed companies and the appointment of directors, which provides a good basis for our research. It should be noted that the direct impact of punishments against interlocking company is not the focus. The punished company must respond until the problem is solved. We pay close attention to the influence of punishments against interlocking company on the accounting information comparability of the observing company through the channel of interlocking directors. We find that the observing company that has common director with the interlocking company will significantly improves the accounting information comparability within two years after the interlocking company is punished, which proves 
that the punishments against listed company has spillover effect.

The contributions of this paper may be as follows:

(1) The paper enriches the study of the consequences of punishments against listed company. The previous literatures mainly investigate the direct consequences of regulatory punishment and the contagious spillover effect caused by punishment, but few papers pay attention to the contrast spillover effect of punishment. We think that the punishment against listed companies by regulatory authorities can have a knock-on effect on the observing company through the channel of interlocking directors, which shows that the purpose of punishments against listed companies by regulatory authorities is not only to expose the illegalities of listed companies and effectively curb their re-occurrence, but also to improving the behavior of unpunished observing company by playing an exemplar role.

(2) The paper enriches the research on the influencing factors of accounting information comparability. The research on the influencing factors of accounting information comparability in the previous literatures is mainly based on the assumption of independent decision-making and does not consider the interaction between companies. As a matter of fact, many companies' decisions affect each other. We use the external factors that bear on interlocking companies to absorb the impact of the illegalities that are punished, according to the method of De Franco (2011) ${ }^{[27]}$ to estimate the degree of change of accounting information comparability, and study the impact of interlocking company on the accounting information comparability of observing company.

\section{Literature review and research hypothesis}

Firstly, we review the relevant literatures from three aspects: the interlocking directors, the spillover effect of punishment and the accounting information comparability. Secondly, we analyze the interlocking directors and that transfer of the punishment experienced to observing company as a channel and how it improves the accounting information comparability of observing company.

\subsection{Interlocking directors}

At present, with the popularity of interlocking directors, the corporate networks based on interlocking directors are commonly established. The previous literatures show that interlocking directors can help company to achieve information transmission.

Battiston et al. (2003) ${ }^{[16]}$ find that corporate decision-making information would be disseminated through shared directors of different companies. Kang $(2008)^{[7]}$ believes that voluntary payment of stock option grants may be driven by social influence and learning within directors networks. Bizjak et al.(2009) ${ }^{[21]}$ find that if directors had previously engaged in similar backdating behavior in other companies, the possibility of backdating stock options would be greatly increased. Chiu et al.(2013) ${ }^{[28}$ find that if a company is linked to another company through interlocking directors, and the interlocking company has had financial restatement events in the same year or two years ago, then the company has a greater probability of financial restatement. Fracassi (2016) ${ }^{[23]}$ finds that managers' financial decisions are influenced by peers with social connections, and the more connections between two companies, the more similar decisions they make.

Domestic research on the information transmission of interlocking directors is also very rich. Li Minna and Wang Tieman (2014) ${ }^{[17]}$ point out that company can learn from companies with good salary incentive practices through directors' network to adjust their salary incentive policies. Liu Yongtao et al. (2015) ${ }^{[18]}$ study the impact of interlocking directors on the choice of accounting policies through information transmission mechanism, and find that company with interlocking relationships are more likely to choose the accounting policy of capitalization of development expenditure. Han Jie et al. (2015) ${ }^{[22]}$ find that the company would learn and imitate the R\&D investment decisions of the interlocking companies. Chen Yunsen and Zheng Dengjin (2017) ${ }^{[24]}$ examine the impact of directors' network on the convergence of investment between companies. If there are interlocking directors between two companies, the investment level and investment changes between companies are more similar. Han Jie et al. (2017) ${ }^{[25]}$ find that there is a connection between two companies, accounting methods, including inventory valuation and depreciation methods were similar, which showed that the choice of accounting methods could be spread through director linkage. Zhou Xiaosu et al. (2017) ${ }^{[19]}$ find that there was inter-organizational imitation in the choice of accounting policies.

It can be seen that interlocking directors are cost-free and reliable channels of information transmission among companies, which can become the dissemination mechanism of inter-company practice.

\subsection{Spillover effect of punishment}


Spillover effect originally means that when a solution exceeding its capacity is added to a container, the solution overflow affects other instruments outside the container. That is, when an organization carries out an activity, it will not only produce the expected effect on the activity, but also have an impact on other person or organization, and its essence is an external effect ${ }^{[29]}$. Trevino $(1992)^{[5]}$ holds that punishment is a social event and studies the influence of punishment on the observer. It shows that punishment will not only have an impact on the punished company, but also have an impact on the unpunished organizations or individuals associated with the punished company, that is, the punishment has spillover effect. Lang and Stula (1992) ${ }^{[30]}$ find that spillover effect of punishment can be divided into contagious effect and contrast effect, contagious effect means that punishment has a negative impact on the punished, but also on other unpunished company, and contrast effect means that the punishment behavior has the opposite, positive effect on other unpunished company.

Many scholars have paid attention to the contagious effect of punitive behavior. Fich and Shivdasani (2007) ${ }^{[6]}$ investigate the impact of financial fraud on the reputation of external directors and find that interlocking company with the same directors also showed a decline in valuation in litigation applications. Kang $(2008)^{[7]}$ find that reputational punishment may spread from the accused company to the interlocking company through the interlocking directors' network. The market value of accused companies will also fall on the day - that is market value of the accused companies decline. Yin Li and Chen Shou (2010) ${ }^{[8]}$ find that group member companies with the financial crisis will have a negative externality impact on affiliated member companies. Beatty(2013) ${ }^{[9]}$ believes that regulatory punishment decisions not only have a significant negative impact on the punished company, but also affect unpunished individuals or organizations. Zhang Yue et al.(2018) ${ }^{[4]}$ find that the company and other stakeholders showed strong negative reactions to the announcement of illegal filing before and after the announcement of illegal listed companies,.

In addition, some literatures argue that spillover effect of punishment not only has a similar effect on other organizations and sometimes has a contrasting positive effect. Jennings et al. ${ }^{[31]}$ (2011) find that company reduce discretionary accrued earnings after peer companies in the same industry were investigated by SEC for manipulation of earnings. Zhong et al. (2017) ${ }^{[32]}$ find that directors subject to regulatory sanctions in another company were more likely to attend board meetings and play supervisory role more effective. Liu Wenjun et al. (2017) ${ }^{[13]}$ find that the auditors with common work experience with punished auditors more incline to issue non-standard audit opinions to customers in the future because of their common audit experience. Yang Jinfeng et al. (2018) ${ }^{[15]}$ find that compared with the unpunished certified public accountant, the audit quality of the punished certified public accountant and his colleagues has been improved using the CSRC administrative punishment decision. Brown et al. (2018) ${ }^{[33]}$ find that if SEC comments on the disclosure of risk factors of industry leaders, competitors or peers, companies that did not receive any comments largely revised their disclosures the following year.

To sum up, the spillover effect of punishment is manifested in the capital market performance and behavior of peers, both contagion effect and contrast effect are rich, but there are also shortcomings. First, most of the channel of spillover effect of punishment revolve around the same region and industry, and there is little discussion about interlocking directors as the path of spillover effect. Second, there are few literatures that study the spillover effect of punishment against listed companies on their accounting information quality.

\subsection{Accounting information comparability}

Accounting information comparability is one of the important quality characteristics of accounting information, which means that different company accounting systems should produce similar accounting information for the same or similar economic business. On the contrary, accounting information should fully reflect the difference when the economic business is different.FASB No.8 (2010) defines the accounting information comparability as the second level of the useful financial information quality feature hierarchy: improving quality.

The research on the economic consequences of the accounting information comparability is very rich. De Franco et al. (2011) ${ }^{[27]}$ believe that the increase of the accounting information comparability can reduce the information collection and treatment cost of the investors, and can reduce the risk and cost of the value evaluation of the participants in the equity capital market. Kim et al. (2013) ${ }^{[34]}$ believe that the accounting information comparability can help to reduce the uncertainty of the perceived risk of bond and CDS market participants, thereby reducing the cost of debt financing. Yang Zhonghai et al. (2015) ${ }^{[35]}$ think that the improvement of the financial report comparability can significantly lower the equity capital cost. Jiang Xuanyu 
et al. (2017) ${ }^{[36]}$ find that the accounting information comparability can help to overcome the market friction and promote companies innovation. Xie Hongshuang et al. (2017) ${ }^{[37]}$ find that improvement of the accounting information comparability can significantly improve the dynamic adjustment speed of the capital structure. Yuan Zhenchao and Rao Pingui (2018) ${ }^{[38}$ find that the comparable performance of accounting information can effectively alleviate the information asymmetry faced by companies. It can be seen that the improvement of the accounting information comparability can help the company to transmit positive signals in the capital market, and can also help the information users to improve the decision-making usefulness of accounting information.

The previous literatures show that influencing factors of the accounting information comparability mainly include standard convergence, strategic differences, internal control, CEO tenure and so on. Wan Peng and Chen Xiangyu (2017) ${ }^{[39]}$ find that the international convergence of accounting standards indirectly affects the information disclosure behavior of the company through the accounting information comparability, and the international convergence of accounting standards improves the financial statements comparability. Zhou Donghua and Yang Xiaokang (2018) ${ }^{[40]}$ show that insider trading can significantly reduce the accounting information comparability. Zhang Xianzhi et al.(2018) ${ }^{[41]}$ find that the more the company strategy deviates from the conventional strategy of the industry, the lower the financial reports comparability, and the improvement of the quality of internal control can lead to improving the financial reports comparability. Chen Guohui and Yin Jian (2018) ${ }^{[42,43]}$ examine that CEO tenure and CFO experience significantly affect the accounting information comparability.

Most of the studies focus on how the corporate independent decision-making affects the accounting information comparability, and few literatures discusses the external factors that affect the accounting information comparability. We study the relationship between the external shock that punishment against interlocking company and accounting information comparability of observing company.

\subsection{Spillover effect of punishment against interlocking company on accounting information comparability of observing company}

It conveys the signal of its operation and financial problems to the market when interlocking company is punished, which will be paid special attention by investors. Observing company which has same director with interlocking company will also be re-examined by investors ${ }^{[7]}$. Compared with the unpunished companies, the observing company need to take positive action to highlight its advantages in order to reduce the negative investor sentiment caused by punishment against interlocking company and maintain their image in the corporate network.

First, the observing company will avoid violations. Trevino(1992) ${ }^{[5]}$ believes that punishment has a deterrent effect, that enhances the risk perception of observers, and reduces similar violations in the future. When the observing company which has interlocking relationship with the punished interlocking company observes that the interlocking company is punished because the illegal behavior through the interlocking directors, it will subconsciously improve the risk perception of illegal behavior, and consider the potential punishment cost caused by illegal behavior to avoid the re-occurrence of illegal behavior, so as to reduce the uncertainty of accounting treatment and improve the quality of accounting information.

Second, the observing company will send a positive signal to the capital market. According to the signal theory of Spence (2002) ${ }^{[26]}$, under the condition of asymmetric information, company needs to adopt appropriate signals to transmit information. If the signal is cheap and easy to imitate, the signal clarification is less reliable, the clarification effect is poor and limited. Only by adopting a way that imitators can not emulate can send credible signals to investors, the clarification effect is good, and it is easier to form a contrast positive effect. So in order to maintain the image and enhance the confidence of investors, the observing company will choose the behavior and signal that other companies are difficult to imitate, and send a positive signal to the capital market.

The accounting information comparability can help to transfer high-quality signals to the capital market as a "improve quality characteristic" in the hierarchical structure of useful financial information. The FASB points out that if comparable accounting information is not available, it is not possible to make investment and credit decisions in a rational and effective manner. If the capital market is not complete, the investors need to identify the relative investment value and risk of the company more clearly by comparing the financial statement, operating results and cash flow of the observing company with other companies. Compared with the other accounting information quality characteristics such as the correlation, the robustness and the earnings quality, the accounting information comparability can determine the quality of the accounting information of the observing 
company through the horizontal comparison among the companies in the industry, so as to be more consistent with the decision-making characteristics of the investors. In addition, compared with other accounting information characteristics, the comparability is a relative index, which needs to be compared with the similar accounting information of other companies and the measure is consistent as far as possible. This makes it difficult for information to be manipulated through choosing the independent accounting policies and method selections. Thus, the accounting information comparability is an imitative information feature. In general, when the interlocking company is punished, the observing company may choose to improve the accounting information comparability to highlight its advantages and increase the investor's confidence.

The above discussion leads to first hypothesis:

Hypothesis 1: Compared with the companies that interlocking company is not punished, the observing company that interlocking company is punished will improve the accounting information comparability.

Some studies have shown that there is a negative correlation between the quality of $t$ board and financial reporting fraud ${ }^{[4,45]}$, so the punishment against listed companies increases the uncertainty of the effective supervision of the punished board, and the directors' supervise and advise ability is likely to be questioned. At the same time, Srinivasan (2005) ${ }^{[46]}$ finds that directors who had experienced accounting re-statement were severely punished by the labor market. Fich and Shivdasani (2007) ${ }^{[6]}$ find that the number of board seats on external directors decreased significantly after financial fraud litigation. The regulatory authorities announce the illegal acts, investigation results and punishment decisions of listed companies on the media (such as the Shanghai Stock Exchange or Stock Exchange website) or the company home page, that will bring multi-dimensional punishment for reputation and qualification to the directors involved, and affect the career of the directors. Fama (1980) ${ }^{[47]}$, Fama and Jensen $(1983)^{[48]}$ believe that directors are constrained by the human capital market and have the motivation to perform their duties well and convey their reputation to the outside. Therefore, in order to make up for the heavy reputation damage suffered in the punished company, the directors who experience punishment have a strong motivation, not only to the punished company, but also to the other companies they also serve, to supervise and advise effectively.

The key to the effective implementation of supervision and advice by interlocking directors is to improve the ability of supervision and advice. According to the cognitive learning theory, Chen Guoquan and Sun Rui $(2013)^{[49]}$ put forward that the behavior corrector will correct the bad action, establish the cognitive reconstruction, and then shape the new behavior according to their experience. The interlocking directors are the bearers of the punishment of the interlocking company or the participants in the illegal behavior. They have a deep understanding about the business operation, financial situation and other information of the interlocking company, and know the cause, process and result of the violation. According to the experience accumulated in the punishment and knowledge and information acquired in the punishment, the interlocking directors establish cognitive reconstruction, that actively corrects the wrong behavior, and learns new methods and knowledge in order to improve their ability to supervise and advise. Hillman and Dalziel(2003) ${ }^{[50]}$ believe that directors' experience and professional knowledge are an important part of board capital, which is conducive to the improvement of board supervision and consultation function. In addition, according to the information transmission function of interlocking directors, the interlocking directors will pass on the experience and corrective behavior accumulated in the punishment against interlocking company to the observing company, so that the interlocking directors can implement effective supervision suggestions in the observing company. Chen Yunsen et al. (2018) ${ }^{[51]}$ think that improving the directors' ability of supervision and suggestion is helpful to the improvement of company perform, while Peasnell et al. (2005) ${ }^{[52]}$ and Chen et al. (2015) find that directors strengthen corporate governance and play a key role in the quality of financial reporting, Faleye and Hoitash (2011) ${ }^{[53]}$ think that the supervision function of the board is mainly reflected in the financial reporting quality.Zhong (2017) ${ }^{[32]}$ also shows that interlocking directors with supervision experience and punishment experience can serve to improve the financial reporting quality.

As mentioned before, compared with other accounting information quality characteristics, the accounting information comparability can reveal the value of the company more deeply and provide more meaningful information to the investors. Therefore, improving the accounting information comparability is one of the key levels to improve the quality of the financial report. In sum, we think that interlocking directors improve the ability of supervision and suggest through performance correction that the interlocking directors experience the company punishment, acts to improve the corporate governance level of the observing company, and can improve the accounting information comparability of the observing company further. 
Overall, this leads us to second hypothesis.

Hypothesis 2: Compared with before interlocking company is punished, the observing company will improve the accounting information comparability after interlocking company is punished.

\section{Research design}

\subsection{Sample and data}

We obtain the data used to measure the accounting information comparability from 2008 to 2019 from the CSMAR database, the Wind database and the Ruisi database, and the data on the directors of all A-share listed companies in Shanghai and Shenzhen and the data on the punishment of all A-share listed companies in Shanghai and Shenzhen are obtained from the CSMAR database. Because the research object of this paper is the spillover effect brought by the punished interlocking company, the type of punishment and the institution for implementing the punishment are not divided in the data treatment process (Shanghai Stock Exchange, Shenzhen Stock Exchange, China Securities Regulatory Commission and the Ministry of Finance).

The data of this paper eliminate the following samples in the process of treatment: (1) excludes samples without interlocking companies; (2) removes the samples of all financial industries; (3) all the observing companies that are punished during the sample period are deleted because we examines the spillover effect of punishment against interlocking company, that is, the impact of regulatory punishment on the relevant unpunished company; (4) the owners' equity is negative, and the IPO company and the company with lack of data are excluded. In the end, we got 6034 observations. In order to control the outlier problem, all continuous variables are winsorized at bottom $1 \%$ and top $99 \%$. The econometric analysis software of this paper is Stata15.0.

\subsection{Definition of variables}

\subsubsection{Dependent variable — The degree of change of accounting information comparability}

In this paper, the degree of change of the accounting information comparability of the observing company from the previous period ( $\mathrm{t}-1)$ to the current period of (t) (Dcomp) is taken as the dependent variable. The calculation process is as follows:

First of all, calculate the accounting information comparability of the observing company.

Following De Franco (2011) $)^{[27]}$, we measure accounting information comparability using data for 16 consecutive quarters, and use Basu's (1997) ${ }^{[54]}$ model to control the effects of earnings recognition conservatism, that is, the asymmetry between the recognition of good news and bad news. We estimate equation (1) of the interaction term of the dummy variable for stock returns and calculate:

$$
\text { Earning }_{i t}=\alpha_{i}+\beta_{i} \operatorname{Return}_{i t}+\chi_{i} \mathrm{Neg}_{i t}+\gamma_{i} \mathrm{Neg}_{i t} \times \operatorname{Re} \mathrm{Rurn}_{i t}+\varepsilon_{i t}
$$

where Earnings $s_{i t}$ is the adjusted accounting earnings that offset the fair value gains and losses that they included of company $i$ in period t. Return ${ }_{\text {it }}$ is the stock price return of company $\mathrm{i}$ in period $\mathrm{t}$. $\mathrm{Neg}_{\mathrm{it}}$ is defined as a dummy variable; if the annual stock return is negative, it equals one; otherwise, it equals zero. Under the framework in equation (1) $\hat{\alpha}_{i}, \hat{\beta}_{i}, \hat{\chi}_{i}$, and $\hat{\gamma}_{i}$ proxy for the accounting function f() for company $\mathrm{i}$, and we use the estimated accounting functions of company $i$ and company $j$ to predict what their earnings. We use the two estimated accounting functions for each company with the economic event of a single company under the framework in equation (2) and equation (3), where $\mathrm{E}\left(\right.$ Earnings $\left._{\mathrm{iit}}\right)$ is the predicted accounting earnings of company i given company i's function and company i's return in period t, and $\mathrm{E}\left(\right.$ Earnings $\left.\mathrm{s}_{\mathrm{jit}}\right)$ is the predicted accounting earnings of company $j$ given company $j$ 's function and company $i$ 's return in period $t$.

$$
\begin{aligned}
& E\left(\text { Earnings }_{i i t}\right)=\hat{\alpha}_{i}+\hat{\beta}_{i} \operatorname{Re} \text { turn }_{i t}+\hat{\chi}_{i} N e g_{i t}+\hat{\gamma}_{i} N e g_{i t} \times \operatorname{Re} t u r n_{i t} \\
& E\left(\text { Earnings }_{i j t}\right)=\hat{\alpha}_{j}+\hat{\beta}_{j} \operatorname{Re} \text { turn }_{i t}+\hat{\chi}_{j} N e g_{i t}+\hat{\gamma}_{j} N e g_{i t} \times \operatorname{Re} t u r n_{i t}
\end{aligned}
$$

The accounting information comparability between companies $i$ and $j$ (Compijt) during period $t$ is defined as the negative value of the average absolute difference between the predicted earnings using company i's and company $\mathrm{j}$ 's functions, calculated by the following equation (4): 


$$
\text { Comp }_{i j t}=-\frac{1}{16} \times \sum_{t-3}^{t} \mid E\left(\text { Earnings }_{i i t}\right)-E\left(\text { Earnings }_{i j t}\right) \mid
$$

where Comp $\mathrm{ijt}_{\mathrm{ijt}}$ is the accounting information comparability for each company $\mathrm{i}-$ company $\mathrm{j}$ combination for $\mathrm{j}$ companies within the same industry in year t. Higher values indicate higher accounting information comparability. We rank all $\mathrm{j}$ values of Comp $\mathrm{p}_{\mathrm{ijt}}$ for each company $\mathrm{i}$ from highest to lowest and calculate the average Comp $p_{\mathrm{ijt}}$ of the four company j's with the highest comparability with company $\mathrm{i}$ (Comp4) during period $\mathrm{t}$, the average Comp $\mathrm{ijt}_{\mathrm{it}}$ of the ten company $\mathrm{j}$ 's with the highest comparability with company $\mathrm{i}$ (Comp10) during period $t$, the median Comp $\mathrm{ijt}_{\mathrm{jt}}$ for all companies in the same industry as company i during period $\mathrm{t}(\mathrm{Compm})$ and the mean Comp $\mathrm{ijt}_{\mathrm{jt}}$ for all companies in the same industry as company i during period $\mathrm{t}$ (Compa).

Secondly, we measure the change degree of the accounting information comparability in t period (Dcomp), that is, the accounting information comparability in period $t$ minus the accounting information comparability in period $\mathrm{t}-1$, and the calculation method is such as formula (5).

$$
\text { Dcomp }_{i, t}=\text { Comp }_{i, t}-\text { Comp }_{i, t-1}
$$

Dcomp is positive, that is to say, the accounting information comparability in period $t$ is higher than that in period $\mathrm{t}-1$, which indicates that the companies improves the accounting information comparability, on the contrary, it means that the accounting information comparability is weakened. We measure the degree of change of the accounting information comparability using degree of change of Comp4 (Dcomp4), degree of change of Compm (Dcompm), degree of change of Comp10 (Dcomp10) and degree of change of Compa(Dcompa).

\subsubsection{Independent variable_—Whether the interlocking company is punished or not}

\section{Horizontal angle}

Horizontal angle means that the accounting information comparability of the observing company that the interlocking company is punished significantly higher than that of the interlocking company that is not punished, that is hypothesis 1.In order to test hypothesis 1, we establish the independent variable P_after.P_after is s a dummy variable, which represents whether the observing company occurs the event that interlocking company is punished. If the observing company occurs the event that the interlocking company is punished for the first time during the sample period, the $\mathrm{P}_{-}$after is equal to1 in the two years after the year, which the interlocking company is punished, otherwise $P \_$after is equal to 0 . In the year which interlocking company is punished, it will not have an impact on the behavior of the observing company, so $P_{-}$after is equal to 0 . If the observing company doesn't occur the event that the interlocking company is punished during the sample period, $\mathrm{P} \_$after is equal to 0 . Two years is due to the short duration of the market disciplinary mechanism, and we find that the impact of interlocking company on the accounting information comparability of the observing company will be weakened after more than two years of punishment.

\section{Longitudinal angle}

Longitudinal angle means that the accounting information comparability of the observing company that the interlocking company is punished is significantly higher than that before that the interlocking company is punished, that is hypothesis 2 . In order to test hypothesis 2 and set the independent variable, After as a dummy variable, due to the limited impact of market disciplinary mechanism on the accounting information comparability, we only choose the window period of two years before and after the punishment against interlocking company, which can be divided into the following five times:-2, -1, 0, 1,2. Among them, "-" represents the time before the interlocking company is punished,"0" represents the year that the interlocking company is punished. " +" represents the time after the interlocking company is punished. In period 1 and 2, After is equal to 1 ,otherwise After is equal to 0.The reason why After was 0 in period 0 is that the punishment announcement of the interlocking company will not have a substantial impact on the behavior of the observing company.

\subsubsection{Control variables}

According to Fang Hongxing (2017) ${ }^{[55]}$, Zhou Donghuan and Yang xiaokai ${ }^{[40]}$, Chen Guohui (2018) ${ }^{[42]}$,we select control variables that may affect the accounting information comparability of listed companies. There are some variables that representing the basic characteristics of Listed Company, such as debt assets ratio (Lev), 
company size (Size), price to book ratio $(\mathrm{Mb})$ and growth rate of revenue(Grow), return on total assets( ROA), earning management (DA), List age(Age) and State ownership(Soe), and some variables that represent the internal governance mechanism of listed companies, including CEO duality (Dual), Ownership concentration (H1), Proportion of independent directors (Indepen) and Board size (Board). In addition, the model also controls year and industry effects respectively.

Table 1. Definition and Measure of Control Variables

\begin{tabular}{|c|c|c|}
\hline Variable & Definition & Measure method \\
\hline Size & Company size & natural logarithm of firm's total assets \\
\hline Lev & Debt assets ratio & total liabilities / total assets \\
\hline Roa & Return on total assets & Net income/total assets \\
\hline Grow & growth rate of revenue & $\begin{array}{l}\text { (Amount of revenue this year - amount of revenue } \\
\text { previous year)/ Amount of revenue previous year }\end{array}$ \\
\hline $\mathrm{Mb}$ & Price to book ratio & $\begin{array}{l}\text { Current closing price shareholders/(equity ending balance } \\
\text { /Subscribed Capital ending balance) }\end{array}$ \\
\hline DA & Earning management & $\begin{array}{l}\text { The absolute value of manipulability accrued earnings } \\
\text { using the Jones Model }\end{array}$ \\
\hline Age & List age & year - listed year \\
\hline Soe & State ownership & $\begin{array}{l}\text { Equal to } 1 \text { if the focal firm is controlled by state and } 0 \\
\text { otherwise }\end{array}$ \\
\hline $\mathrm{H} 1$ & Ownership concentration & proportion of the first largest shareholder \\
\hline Indepen & $\begin{array}{l}\text { Proportion of } \\
\text { independent directors }\end{array}$ & $\begin{array}{l}\text { the ratio of the number of independent directors to the } \\
\text { total number of directors on board }\end{array}$ \\
\hline Board & Board size & The natural logarithm of total number of directors \\
\hline Dual & CEO duality & $\begin{array}{l}\text { Equal to } 1 \text { if the CEO also holds the position of board } \\
\text { chair and } 0 \text { otherwise }\end{array}$ \\
\hline
\end{tabular}

Note: In the regression results, all variables with L. preceded represent the value of the lag period of the variable.

\subsection{Model}

\subsubsection{Horizontal angle}

we used the following regression model (6) in order to test the Hypothesis 1:

$$
\text { Dcomp }_{i, t}=\beta_{0}+\beta_{1} P_{-} \text {after }_{i, t}+\beta_{2} \text { Control }_{i, t-1}+\sum \text { Year }+\sum \text { Ind }_{+} \varepsilon_{i, t-1}
$$

\subsubsection{Horizontal angle}

we used the following regression model (7) in order to test the Hypothesis 2:

$$
\text { Dcomp }_{i, t}=\beta_{0}+\beta_{1} \text { After }_{i, t}+\beta_{2} \text { Control }_{i, t-1}+\sum \text { Year }_{+} \text {Ind }_{+\varepsilon_{i, t-1}}
$$

Among them, the difference between model (6) and model (7) is that model (6) takes all listed companies (including punished interlocking company and unpunished interlocking company) as the research object, while model (7) only takes the punished companies of interlocking company as the sample.

\section{Empirical results and analysis}

\subsection{Summary statistics}

Table 2 shows the summary statistics, including observations, mean, standard deviation, minimum, median and maximum. The observations in this paper are 6034. Among them, the independent variable is the difference between period $t$ and period t-1, so our sample contains observation 4974 in the last. The average and median of the four indicators (Dcompa, Dcomp4, Dcompm and Dcomp10) are basically 0, which indicates that the degree of improving the accounting information comparability in the whole sample is very limited. The average value of return on assets (Roa) is 0.043 , the maximum value is 0.211 , the minimum value is -0.142 ; the average company size (Size) is 22.48 ; the average Lev is 0.467 , which conforms to the reality of China; the average annual growth rate of revenue (Grow) of sample companies is 0.153 , the maximum value is 2.475 , and the minimum value is -0.522 , which is in line with the reality of China. The difference of growth among companies is relatively large; the average level of earnings management (DA) is 0.066 , the maximum value is 0.467 , the minimum value is 0.001 , and the degree of earnings manipulation among companies is also quite different. The average ratio of 
independent directors (Indepen) is 0.371 , which accord with the relevant regulations of Chinese listed companies.

Table 2 Descriptive Statistics of Samples

\begin{tabular}{lcccccc}
\hline variable & $\mathrm{N}$ & mean & $\mathrm{sd}$ & $\mathrm{min}$ & $\mathrm{p} 50$ & $\mathrm{max}$ \\
\hline Dcompa & 4974 & 0 & 0.009 & -0.193 & 0 & 0.121 \\
Dcompm & 4974 & 0 & 0.010 & -0.200 & 0 & 0.123 \\
Dcomp10 & 4974 & 0 & 0.006 & -0.153 & 0 & 0.079 \\
Dcomp4 & 4974 & 0 & 0.006 & -0.162 & 0 & 0.074 \\
Size & 6034 & 22.48 & 1.339 & 19.72 & 22.31 & 26.44 \\
Lev & 6034 & 0.467 & 0.196 & 0.070 & 0.473 & 0.897 \\
Roa & 6034 & 0.043 & 0.051 & -0.142 & 0.037 & 0.211 \\
Grow & 6034 & 0.153 & 0.373 & -0.522 & 0.100 & 2.475 \\
Mb & 6034 & 0.622 & 0.248 & 0.123 & 0.620 & 1.128 \\
DA & 6034 & 0.066 & 0.076 & 0.001 & 0.043 & 0.467 \\
Age & 6034 & 2.486 & 0.470 & 1.386 & 2.565 & 3.219 \\
Soe & 6034 & 0.601 & 0.490 & 0 & 1 & 1 \\
H1 & 6034 & 36.87 & 15.36 & 9.090 & 35.79 & 77.07 \\
Indepen & 6034 & 0.371 & 0.054 & 0.308 & 0.333 & 0.571 \\
Board & 6034 & 2.181 & 0.193 & 1.609 & 2.197 & 2.708 \\
Dual & 6034 & 0.183 & 0.386 & 0 & 0 & 1 \\
\hline
\end{tabular}

\subsection{Basic regression results}

\subsubsection{Horizontal angle}

Table 3 is the basic regression result of model (6). The coefficient on $\mathrm{P} \_$after is significantly positive, it shows that the accounting information comparability of the observing company that interlocking company is punished is indeed significantly improved compared with the companies that interlocking company is not punished, and hypothesis 1 is supported. About the control variables, Age, Grow and Indepen has a significant positive impact on the accounting information comparability, which indicates that the better the operating ability of the company, the longer the listed age and the higher the proportion of independent directors, the more likely to improve the accounting information comparability, but Lev has a significant negative impact, indicating that the higher the debt ratio, the more likely to reduce the accounting information comparability.

Table3 Regression Results of $\operatorname{Model}(6)$

\begin{tabular}{|c|c|c|c|c|}
\hline VARIABLES & $\begin{array}{c}\text { Dcompa } \\
\text { (1) }\end{array}$ & $\begin{array}{c}\text { Dcomp4 } \\
\text { (2) }\end{array}$ & $\begin{array}{c}\text { Dcompm } \\
\text { (3) }\end{array}$ & $\begin{array}{c}\text { Dcomp } 10 \\
\text { (4) }\end{array}$ \\
\hline P_after & $\begin{array}{c}0.001 * * * \\
(3.20)\end{array}$ & $\begin{array}{c}0.000 * * \\
(2.05)\end{array}$ & $\begin{array}{c}0.001 * * * \\
(3.28)\end{array}$ & $\begin{array}{c}0.000 * * \\
(2.39)\end{array}$ \\
\hline 1Size & $\begin{array}{l}-0.000 \\
(-1.25)\end{array}$ & $\begin{array}{l}-0.000 \\
(-0.38)\end{array}$ & $\begin{array}{l}-0.000 \\
(-1.02)\end{array}$ & $\begin{array}{l}-0.000 \\
(-0.62)\end{array}$ \\
\hline lLev & $\begin{array}{c}-0.004 * * * \\
(-2.83)\end{array}$ & $\begin{array}{c}-0.002 * * \\
(-2.03)\end{array}$ & $\begin{array}{c}-0.004 * * * \\
(-2.60)\end{array}$ & $\begin{array}{c}-0.002 * * \\
(-2.00)\end{array}$ \\
\hline IRoa & $\begin{array}{l}0.002 \\
(0.45)\end{array}$ & $\begin{array}{l}0.005 \\
(1.51)\end{array}$ & $\begin{array}{l}-0.000 \\
(-0.05)\end{array}$ & $\begin{array}{l}0.004 \\
(1.33)\end{array}$ \\
\hline 1Grow & $\begin{array}{c}0.001 * \\
(1.82)\end{array}$ & $\begin{array}{c}0.001 * * * \\
(2.83)\end{array}$ & $\begin{array}{l}0.001 \\
(1.45)\end{array}$ & $\begin{array}{c}0.001 * * \\
(2.56)\end{array}$ \\
\hline $1 \mathrm{Mb}$ & $\begin{array}{l}0.000 \\
(0.21)\end{array}$ & $\begin{array}{l}0.000 \\
(0.31)\end{array}$ & $\begin{array}{l}-0.001 \\
(-0.79)\end{array}$ & $\begin{array}{l}-0.000 \\
(-0.04)\end{array}$ \\
\hline IDA & $\begin{array}{l}0.001 \\
(0.76)\end{array}$ & $\begin{array}{l}-0.002 \\
(-1.57)\end{array}$ & $\begin{array}{l}0.001 \\
(0.73)\end{array}$ & $\begin{array}{l}-0.001 \\
(-0.86)\end{array}$ \\
\hline 1Age & $\begin{array}{c}0.001 * * \\
(2.38)\end{array}$ & $\begin{array}{l}0.000 \\
(1.02)\end{array}$ & $\begin{array}{c}0.001 * * \\
(2.32)\end{array}$ & $\begin{array}{l}0.000 \\
(1.33)\end{array}$ \\
\hline 1Soe & $\begin{array}{l}-0.000 \\
(-0.07)\end{array}$ & $\begin{array}{l}-0.000 \\
(-0.04)\end{array}$ & $\begin{array}{l}-0.000 \\
(-0.08)\end{array}$ & $\begin{array}{l}-0.000 \\
(-0.40)\end{array}$ \\
\hline
\end{tabular}




\begin{tabular}{lcccc} 
lH1 & 0.000 & -0.000 & $0.000^{*}$ & -0.000 \\
IIndepen & $(1.33)$ & $(-0.34)$ & $(1.68)$ & $(-0.15)$ \\
& $0.006^{* *}$ & 0.001 & $0.007^{* *}$ & 0.002 \\
lBoard & $(2.40)$ & $(0.98)$ & $(2.52)$ & $(1.34)$ \\
& -0.001 & -0.001 & -0.001 & -0.001 \\
lDual & $(-0.76)$ & $(-1.05)$ & $(-1.05)$ & $(-1.24)$ \\
& 0.000 & 0.000 & 0.000 & -0.000 \\
Year & $(0.48)$ & $(0.24)$ & $(0.49)$ & $(-0.15)$ \\
Ind & control & control & control & control \\
Constant & control & control & control & control \\
& 0.003 & 0.002 & 0.003 & 0.003 \\
R-squared & $(0.85)$ & $(0.97)$ & $(0.91)$ & $(1.47)$ \\
Adi_R2 & 0.137 & 0.024 & 0.090 & 0.028 \\
Num & 0.129 & 0.0158 & 0.0821 & 0.0196 \\
\hline
\end{tabular}

Robust t-statistics in parentheses

$* * * \mathrm{p}<0.01, * * \mathrm{p}<0.05, * \mathrm{p}<0.1$

\subsubsection{Longitudinal angle}

Table 4 is the basic regression result for the model (7). The regression coefficient on After is significantly positive when the dependent variable was Dcompa and Dcompm, and the regression coefficient on After was positive but not significant when the dependent variable was Dcomp4 and Dcomp10, which may be due to the fact that the Dcomp4 and Dcomp10 is only mean value of the top four and ten companies, the measurement method of comparability is very strict, so the improvement of this index is not significant. However, the results show that the accounting information comparability of the observing company is obviously improved after the interlocking company is punished, and the hypothesis of the longitudinal angle is also supported. About the control variable, Age has a significant positive effect, the longer the listed company age, the more likely the company is to improve the accounting information comparability. But Size and Lev have a significant negative impact. The larger the size of the company, the higher the proportion of the debt, the more likely the companies can lower the accounting information comparability.

Table 4 Regression Results of Model(7)

\begin{tabular}{lcccc}
\hline \multirow{2}{*}{ VARIABLES } & Dcompa & Dcomp4 & Dcompm & Dcomp10 \\
After & $(1)$ & $(2)$ & $(3)$ & $(4)$ \\
& $0.001^{* *}$ & 0.000 & $0.001^{* *}$ & 0.000 \\
ISize & $(2.22)$ & $(0.92)$ & $(2.13)$ & $(1.54)$ \\
& $-0.001^{* * *}$ & $-0.000^{*}$ & $-0.001^{* * *}$ & $-0.000^{* *}$ \\
ILev & $(-2.60)$ & $(-1.80)$ & $(-2.74)$ & $(-2.22)$ \\
& $-0.002^{*}$ & -0.000 & -0.002 & -0.000 \\
IRoa & $(-1.85)$ & $(-0.63)$ & $(-1.64)$ & $(-0.72)$ \\
& -0.005 & -0.001 & -0.007 & -0.001 \\
1Grow & $(-1.00)$ & $(-0.27)$ & $(-1.38)$ & $(-0.46)$ \\
& 0.000 & 0.000 & -0.000 & 0.000 \\
lMb & $(0.12)$ & $(1.27)$ & $(-0.46)$ & $(0.55)$ \\
& 0.001 & 0.000 & 0.001 & 0.000 \\
IDA & $(1.10)$ & $(0.47)$ & $(0.51)$ & $(0.39)$ \\
& 0.004 & -0.001 & 0.004 & 0.000 \\
1Age & $(1.39)$ & $(-0.47)$ & $(1.49)$ & $(0.31)$ \\
& $0.001^{* *}$ & 0.001 & $0.001^{* *}$ & $0.001 *$ \\
1Soe & $(2.51)$ & $(1.63)$ & $(2.57)$ & $(1.92)$ \\
& 0.001 & 0.000 & 0.000 & 0.000 \\
lH1 & $(1.44)$ & $(0.30)$ & $(1.07)$ & $(0.47)$ \\
& 0.000 & $-0.000^{*}$ & 0.000 & -0.000
\end{tabular}




\begin{tabular}{lcccc} 
& $(0.38)$ & $(-1.94)$ & $(0.52)$ & $(-1.48)$ \\
IIndepen & 0.004 & 0.002 & 0.006 & 0.002 \\
& $(0.99)$ & $(1.04)$ & $(1.60)$ & $(0.78)$ \\
lBoard & -0.001 & 0.000 & -0.000 & -0.000 \\
& $(-0.51)$ & $(0.54)$ & $(-0.13)$ & $(-0.29)$ \\
IDual & 0.000 & 0.000 & 0.000 & 0.000 \\
& $(0.68)$ & $(1.63)$ & $(0.58)$ & $(1.28)$ \\
Year & control & control & control & control \\
Ind & control & control & control & control \\
Constant & $0.009^{*}$ & 0.003 & $0.009^{*}$ & $0.005^{* *}$ \\
& $(1.85)$ & $(1.18)$ & $(1.70)$ & $(2.01)$ \\
R-squared & 0.199 & 0.034 & 0.136 & 0.042 \\
Adi_R2 & 0.182 & 0.0136 & 0.118 & 0.0222 \\
Num & 2075 & 2075 & 2075 & 2075 \\
\hline
\end{tabular}

Robust t-statistics in parentheses

$* * * \mathrm{p}<0.01, * * \mathrm{p}<0.05, * \mathrm{p}<0.1$

\subsection{Propensity-score matching and Difference in difference analysis}

\subsubsection{Propensity-score matching}

The model (6) support hypothesis 1 , which refers to the control group of interlocking company without punishment, but there may be endogenous problems arising from sample selection. For example, the company's improvement of accounting information comparability may be determined by its own situation. Therefore, in order to control the sample selection bias, we adopt the propensity-score matching method.

The first step is to divide the whole sample into two groups according to the $P_{-}$all variable. The sample that $P_{-}$all is equal to 1 constitutes the treatment group and the sample that $P_{-}$all is equal to 0 constitutes the control group. Because matching is to find the closest matching company in the year when the sample company occur the event that the interlocking company is punished for the first time, only the observation which P_once is equal to 1 is selected for the treatment group, and these observation are combined with the control group to form the observation value for calculating the propensity-score. Model (8) Logit regression:

$$
\log i t\left(p_{-} \text {all }_{i, t}=1\right)=\beta_{0}+\beta+\beta_{1} \text { Control }_{i, t}+\varepsilon_{i, t}
$$

Where Control is a matching co-variable, unlike the control variable of model (6), the model (6) uses the value of the lag period and the model (8) uses the current value.

In the second step, run the logit model, calculate the propensity-score of all samples, and then match it year by year, find out the matching company which has the closest propensity-score with the observing company that the interlocking company is punished, and specify the hypothetical treatment year for the matching company. For example, observing company A occur the event that the interlocking company is punished for the first time in 2010, and after finding the closest company B in 2010, company B was designated 2010 as the hypothetical treatment year. In addition to the closest propensity-score, the following conditions should be considered when pairing: (1) matching year by year; (2) matching with replacement method in the same year; (3) matching with no-replacement method between years, that is, the observation that have been selected as matched samples in this year will not participate in the matching in future years.

In the third step, after obtaining the matching group, the matched results and the observation of the treatment group are combined, and the information of the relevant variables is obtained by re-merging with the pre-pairing data. At this point, the matching group is marked as Treat is equal to 0 , and the treatment group is marked as Treat is equal to1. Since both groups of samples have treatment years, the event window can be determined according to the difference between the natural year and the treatment year.

On this basis, we define a similar $P_{-}$after variable for the control group. As mentioned earlier, we limit the sample to the window period $[+1,+2]$. If the observation period is two years after the specified treatment year, the $P_{-}$after is equal to 1 , otherwise, the $P_{-}$after is equal to 0 . For the control group, window period $[+1,+2]$ refers to the control group for two years after the interlocking company is punished, which is counterfactual.

Figures 1 and 2 show the p-score of the treatment and the control group before and after matching, respectively. Before matching, the p-score of the treatment group is higher than that of the control group, and 
after matching, the p-score of the two groups are basically the same. The results showed that the treatment group and the control group satisfy the common support criteria after propensity-score matching.

The fourth step, regression analysis examines the coefficient on P_after. As can be seen from Table 5, the coefficient on P_after is still significantly positive. The results show that the accounting information comparability of the observing company is still significantly improved after propensity-score matching.

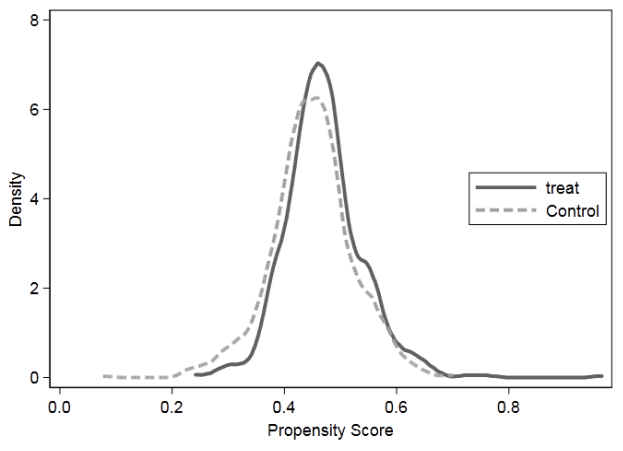

Figure 1 P-SCORE density distributions before matching

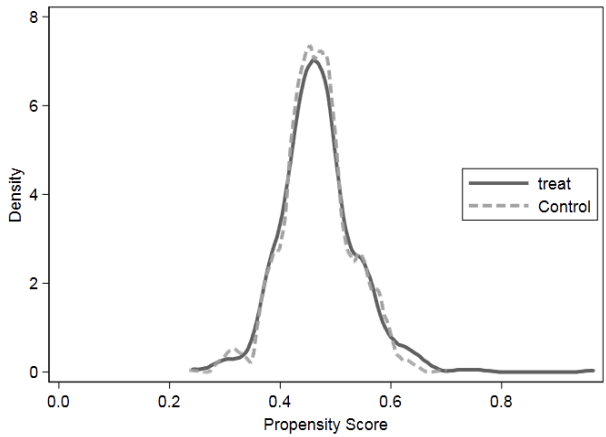

Figure 2 P-SCORE density distributions after matching

Table 5 Regression Results of Model(6)(PSM)

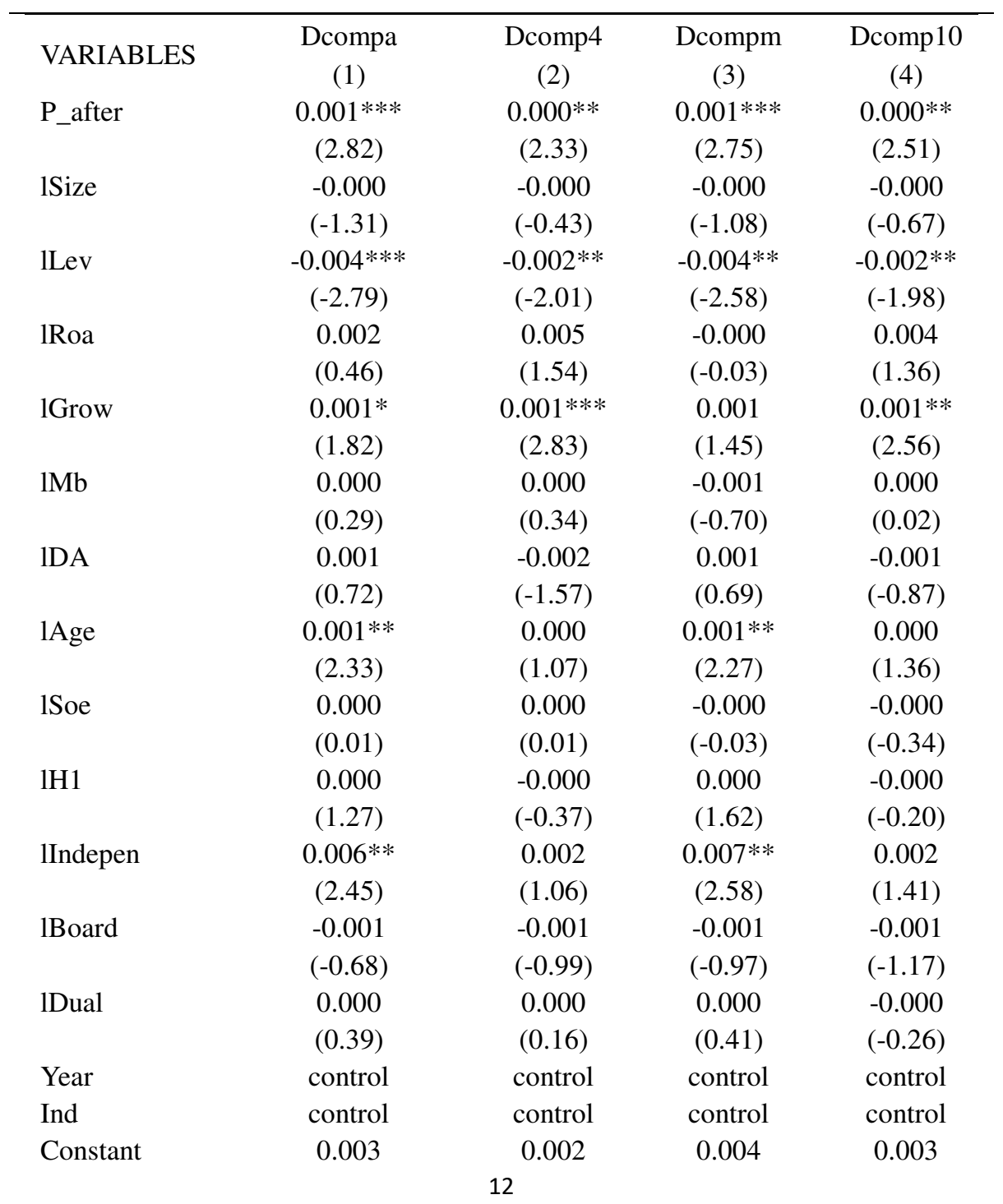




\begin{tabular}{lcccc}
\hline & $(0.87)$ & $(0.91)$ & $(0.93)$ & $(1.41)$ \\
R-squared & 0.136 & 0.024 & 0.089 & 0.028 \\
Adi_R2 & 0.128 & 0.0154 & 0.0812 & 0.0191 \\
Num & 4964 & 4964 & 4964 & 4964 \\
\hline
\end{tabular}

Robust t-statistics in parentheses

$* * * \mathrm{p}<0.01,{ }^{*} * \mathrm{p}<0.05,{ }^{*} \mathrm{p}<0.1$

\subsubsection{PSM-DID}

Although both hypothesis 1 and hypothesis 2 are supported, there are still some shortcomings in basic regression. The difference of accounting information comparability before and after the interlocking company is punished may be the trend of the observing company itself, not because of the impact of interlocking company is punished. In order to solve this problem, we use difference-in-difference estimation based on the previous propensity-score matching.

Because we need to examine the degree of change of accounting information comparability before and after punishment of interlocking company, we still choose the same window period $[-2,+2]$ as model (7). On this basis, we define post variables for treatment group and control group, Post is equal to 1 after the treatment year (for control group, the treatment year is the designated treatment year), otherwise Post is equal to 0. Thereby, there are Treat and Post variables in the model, and the regression coefficient on their interaction terms is the estimator. The model is follows:

$$
\begin{gathered}
\text { Dcomp }_{i, t}=\beta_{0}+\beta_{1} \text { Post }+\beta_{2} \text { Treat }+\beta_{3} \text { Post } * \text { Treat }+\beta_{4} \text { Control }_{i, t-1} \\
+\sum \text { Year }+\sum \text { Ind }+\varepsilon_{i, t-1}
\end{gathered}
$$

Table6 shows the results of psm-did. Three results are reported for four indicators (Dcompa, Dcomp4, Dcompm and Dcomp10) to improve the accounting information comparability. Although only when the dependent variables is Dcompm ,the coefficients on Post*Treat is significantly positive, other dependent variable fail to pass the significance test. The result still shows that after the interlocking company is punished, the observing company will significantly improve its accounting information comparability. Hypothesis 2 has been significantly supported. 
Table6 Results of PSM-DID analysis

\begin{tabular}{|c|c|c|c|c|}
\hline VARIABLES & $\begin{array}{c}\text { Dcompa } \\
\text { (1) }\end{array}$ & $\begin{array}{l}\text { Dcomp4 } \\
\text { (2) }\end{array}$ & $\begin{array}{c}\text { Dcompm } \\
\text { (3) }\end{array}$ & $\begin{array}{c}\text { Dcomp10 } \\
\text { (4) }\end{array}$ \\
\hline Post & $\begin{array}{l}-0.002 \\
(-1.06)\end{array}$ & $\begin{array}{l}-0.001 \\
(-1.51)\end{array}$ & $\begin{array}{l}-0.003 \\
(-1.42)\end{array}$ & $\begin{array}{c}-0.002 * * \\
(-2.07)\end{array}$ \\
\hline Treat & $\begin{array}{l}0.001 \\
(0.41)\end{array}$ & $\begin{array}{l}-0.000 \\
(-0.66)\end{array}$ & $\begin{array}{l}-0.000 \\
(-0.18)\end{array}$ & $\begin{array}{l}-0.000 \\
(-0.36)\end{array}$ \\
\hline Post* Treat & $\begin{array}{l}0.002 \\
(1.09)\end{array}$ & $\begin{array}{l}0.001 \\
(1.61)\end{array}$ & $\begin{array}{l}0.003 \\
(1.40)\end{array}$ & $\begin{array}{c}0.002 * * \\
(2.03)\end{array}$ \\
\hline 1Size & $\begin{array}{l}-0.000 \\
(-0.64)\end{array}$ & $\begin{array}{l}0.000 \\
(1.30)\end{array}$ & $\begin{array}{l}-0.000 \\
(-0.56)\end{array}$ & $\begin{array}{l}0.000 \\
(0.57)\end{array}$ \\
\hline 1Lev & $\begin{array}{c}-0.004 * * \\
(-2.37)\end{array}$ & $\begin{array}{c}-0.002 * * \\
(-2.21)\end{array}$ & $\begin{array}{c}-0.004 * * \\
(-2.34)\end{array}$ & $\begin{array}{c}-0.001 * * \\
(-1.99)\end{array}$ \\
\hline 1Roa & $\begin{array}{c}-0.009 * \\
(-1.78)\end{array}$ & $\begin{array}{c}-0.008 * * * \\
(-3.24)\end{array}$ & $\begin{array}{l}-0.009 \\
(-1.60)\end{array}$ & $\begin{array}{c}-0.007 * * * \\
(-2.74)\end{array}$ \\
\hline 1Grow & $\begin{array}{l}-0.000 \\
(-0.36)\end{array}$ & $\begin{array}{l}-0.001 \\
(-1.25)\end{array}$ & $\begin{array}{l}-0.001 \\
(-0.56)\end{array}$ & $\begin{array}{l}-0.001 \\
(-1.23)\end{array}$ \\
\hline $1 \mathrm{Mb}$ & $\begin{array}{c}-0.001 * \\
(-1.83)\end{array}$ & $\begin{array}{l}0.000 \\
(0.27)\end{array}$ & $\begin{array}{c}-0.002 * * * \\
(-2.66)\end{array}$ & $\begin{array}{l}-0.000 \\
(-0.97)\end{array}$ \\
\hline 1DA & $\begin{array}{c}0.007 * * * \\
(2.63)\end{array}$ & $\begin{array}{l}0.002 \\
(1.29)\end{array}$ & $\begin{array}{c}0.009 * * * \\
(3.06)\end{array}$ & $\begin{array}{c}0.002 * * \\
(1.97)\end{array}$ \\
\hline lAge & $\begin{array}{l}0.000 \\
(0.50)\end{array}$ & $\begin{array}{l}0.000 \\
(0.71)\end{array}$ & $\begin{array}{l}0.000 \\
(0.21)\end{array}$ & $\begin{array}{l}0.000 \\
(1.23)\end{array}$ \\
\hline 1Soe & $\begin{array}{l}0.001 \\
(1.32)\end{array}$ & $\begin{array}{l}0.000 \\
(0.45)\end{array}$ & $\begin{array}{l}0.001 \\
(1.04)\end{array}$ & $\begin{array}{l}0.000 \\
(0.54)\end{array}$ \\
\hline 1H1 & $\begin{array}{c}0.008 * \\
(1.79)\end{array}$ & $\begin{array}{l}0.001 \\
(0.34)\end{array}$ & $\begin{array}{c}0.011 * * \\
(2.21)\end{array}$ & $\begin{array}{l}0.002 \\
(0.93)\end{array}$ \\
\hline IIndepen & $\begin{array}{l}-0.001 \\
(-0.37)\end{array}$ & $\begin{array}{l}-0.001 \\
(-1.42)\end{array}$ & $\begin{array}{l}-0.000 \\
(-0.16)\end{array}$ & $\begin{array}{l}-0.001 \\
(-1.56)\end{array}$ \\
\hline 1Board & $\begin{array}{l}-0.000 \\
(-0.06)\end{array}$ & $\begin{array}{l}0.000 \\
(0.14)\end{array}$ & $\begin{array}{l}-0.000 \\
(-0.45)\end{array}$ & $\begin{array}{l}0.000 \\
(0.16)\end{array}$ \\
\hline 1Dual & $\begin{array}{l}-0.002 \\
(-1.06)\end{array}$ & $\begin{array}{l}-0.001 \\
(-1.51)\end{array}$ & $\begin{array}{l}-0.003 \\
(-1.42)\end{array}$ & $\begin{array}{c}-0.002 * * \\
(-2.07)\end{array}$ \\
\hline Year & control & control & control & control \\
\hline Ind & control & control & control & control \\
\hline Constant & $\begin{array}{l}0.001 \\
(0.23)\end{array}$ & $\begin{array}{l}-0.000 \\
(-0.03)\end{array}$ & $\begin{array}{l}0.001 \\
(0.16)\end{array}$ & $\begin{array}{l}0.001 \\
(0.20)\end{array}$ \\
\hline R-squared & 0.234 & 0.048 & 0.170 & 0.069 \\
\hline Adi_R2 & 0.203 & 0.009 & 0.136 & 0.031 \\
\hline Num & 1088 & 1088 & 1088 & 1088 \\
\hline
\end{tabular}

Robust t-statistics in parentheses $* * * \mathrm{p}<0.01, * * \mathrm{p}<0.05, * \mathrm{p}<0.1$ 


\section{Conclusion}

Based on the spillover effect of punishment and the theory of interlocking directors, this paper explores whether the punishment against listed companies by the regulatory authorities has spillover effect on the observing company which have interlocking relationship with punished interlocking company using the sample of A-share listed companies in Shanghai and Shenzhen stock markets from 2008 to 2019:

Firstly, the observing company significantly improve the accounting information comparability within two years after interlocking company is punished when compared horizontally with the company that interlocking company is not punished. After controlling the bias of sample selection, the conclusion of horizontal angle after propensity score matching is still valid.

Secondly, he observing company also significantly improve the accounting information comparability within two years after the interlocking company is punished when compared vertically with before interlocking company is punished. This conclusion is proved again using psm-did.

Based on the above results, we believe that the observing company will improve the accounting information comparability after the punishment against interlocking company by the regulatory authorities, which shows that the punishment against listed companies will have a contrast spillover effect to other companies through the channel of interlocking directors.

This study has the following enlightenments: (1) The impact of punishment against Listed Companies with interlocking relations indirectly provides supporting evidence for the effectiveness of securities market regulation. Therefore, the regulatory authorities should continue to strengthen the supervision and punishment of capital market irregularities, so as to strengthen the role of the listed companies' punishment, and improve the quality of information disclosure of Listed Companies in China. This will reduce the information asymmetry between investors and listed companies. (2) Another enlightening factor is to play the role of information transmission of interlocking directors actively, while studying the convergence of interlocking directors 'behavior. Also, we should also pay attention to the contrast effect of information transmission of interlocking directors, and provide operational suggestions for companies to establish a good image that transmit positive signals in the company network.

Funding: This work is financially supported by the General Projects of the National Social Science Foundation of China(15BGL068) and Fundamental Research Funds for Central Universities of China(3072019CFJ905).

\section{References:}

[1] Gongmeng C, Ning G. An empirical study of the effectiveness of securities regulation [J]. Management World, 2005(7): 40-47.

[2] Zhou X, Reesor R M. Misrepresentation and capital structure: Quantifying the impact on corporate debt value [J]. Journal of Corporate Finance, 2015,34,293-310.

[3] Yuan Q B, Zhang Y Y. The real effects of corporate fraud: Evidence from class action lawsuits [J]. Accounting and Finance, 2016,56(3): 879-911.

[4] Yue Z. What will company lose? Case study on zixin company. [J]. China Accounting Review, 2018,16(2): 283-307.

[5] Trevino L K. The social effects of punishment in organizations - a justice perspective [J]. Academy of Management Review, 1992,17(4): 647-676.

[6] Fich E M, Shivdasani A. Financial fraud, director reputation, and shareholder wealth [J]. Journal of Financial Economics, 2007,86(2): 306-336.

[7] Kang E. Director interlocks and spillover effects of reputational penalties from financial reporting fraud [J]. Academy of Management Journal, 2008,51(3): 537-555.

[8] Li Y, Shou C. Spillover effects of distress business groups and financial propping from large shareholders [J]. Collected Essays on Finance and Economics, 2010(1): 77-83.

[9] Beatty A, Liao S, Yu J J. The spillover effect of fraudulent financial reporting on peer firms' investments [J]. Journal of Accounting \& Economics, 2013,55(2-3): 183-205.

[10] Jennings J N, Kedia S, Rajgopal S. The deterrent effects of sec enforcement and class action litigation [J]. SSRN Electronic Journal, 2011

[11] Wang D T, Gu F F, Dong M C. Observer effects of punishment in a distribution network [J]. Journal of Marketing Research, 2013,50(5): 627-643. 
[12] Yiu D W, Xu Y H, Wan W P. The deterrence effects of vicarious punishments on corporate financial fraud [J]. Organization Science, 2014,25(5): 1549-1571.

[13] Wenjun L, Xiuzhu L, Bangsheng X. Does it punish one person as a warning to others? A study on the spillover effect of individual auditor punishment: a perspective based on the auditors with common audit experience [J]. Contemporary Accounting Review, 2017,10(2): 86-110.

[14] Chunxia Z, Lu L, Zhisheng L. Study on the impact of the nature of ultimate ownership on listed companies fraud punishment [J]. Review of Investment Studies, 2013,32(11): 101-120.

[15] Jinfeng Y, Zhi C, Xia W, et al. Spillover effects of cpa sanction- from the perspective of close cooperation relationship with disciplined cpa [J]. Accounting Research, 2018(8): 65-71

[16] Battiston S, Weisbuch G, Bonabeau E. Decision spread in the corporate board network [J]. Advances in Complex Systems, 2003,6(4): 631-644.

[17] Minna L, Tienan W. Board network, executive compensation incentive and firm growth [J]. China Soft Science, 2014(4): 138-148.

[18] Yongtao L, Yunsen C, Deren X, et al. Board network and accounting policies'convergence:Evidence based on implicit decision of development cost in china [J]. China Accounting Review, 2015,13(1): 1-30.

[19] Xiaosu Z, Lei W, Chen C. Inter-corporate top managers' ties and accounting information comparability: An empirical study on the perspective of inter-organizational imitation [J]. Nankai Business Review, 2017,20(3): 100-112.

[20] Kang E, Tan B R. Accounting choices and director interlocks: A social network approach to the voluntary expensing of stock option grants [J]. Journal of Business Finance \& Accounting, 2008,35(9-10): 1079-1102.

[21] Bizjak J, Lemmon M, Whitby R. Option backdating and board interlocks [J]. Review of Financial Studies, 2009,22(11): 4821-4847.

[22] Jie H, Bose I, Hu N, et al. Does director interlock impact corporate r\&d investment? [J]. Decision Support Systems, 2015,7,128-136.

[23] Fracassi C. Corporate finance policies and social networks [J]. Management Science, 2017,63(8): 2420-2438.

[24] Yunsen C, Dengjin Z. Board network, information bridge and corporate investment convergence [J]. Nankai Business Review, 2017,20(3): 159-171.

[25] Jie H, Hu N, Liu L, et al. Does director interlock impact the diffusion of accounting method choice? [J]. Journal of Accounting and Public Policy, 2017,36(4): 316-334.

[26] M S. Signaling in retrospect and the informational structure of markets [J]. American Economic Review, 2002,92(3): 434-459.

[27] De Franco G, Kothari S P, Verdi R S. The benefits of financial statement comparability [J]. Journal of Accounting Research, 2011,49(4): 895-931.

[28] Chiu P C, Teoh S H, Tian F. Board interlocks and earnings management contagion [J]. Accounting Review, 2013,88(3): 915-944.

[29] Wei J, Ning L, Zhengtang Z. Organizational punishment from the observer's perspective: A review [J]. Human Resources Development of China, 2014(11): 25-30.

[30] Lang L H P, Stulz R M. Contagion and competitive intraindustry effects of bankruptcy announcements - an empirical-analysis [J]. Journal of Financial Economics, 1992,32(1): 45-60.

[31] Xiaoling L,Zhongyan L. Analysts' attention, professional reputation and accounting information transparency [J]. Journal of Anhui University(Philosophy and Social Sciences Edition), 2014,38(6): $142-149$.

[32] Zhong Q L, Liu Y Y, Yuan C. Director interlocks and spillover effects of board monitoring: Evidence from regulatory sanctions [J]. Accounting and Finance, 2017,57(5): 1605-1633.

[33] Brown S V, Tian X L, Tucker J W. The spillover effect of sec comment letters on qualitative corporate disclosure: Evidence from the risk factor disclosure [J]. Contemporary Accounting Research, 2018,35(2): 622-656.

[34] Kim S, Kraft P, Ryan S G. Financial statement comparability and credit risk [J]. Review of Accounting Studies, 2013,18(3): 783-823.

[35] Yang Z, Zhang L, Li Y. Financial statement comparability and cost of equity capital: Evidence from the a-share listed chinese firms [J]. Contemporary Accounting Review, 2015,8(2): 84-103.

[36] Xuanyu J, Danlin S, Ying L. Does accounting information comparability affect corporate innovation [J]. 
Nankai Business Review, 2017,20(4): 82-92.

[37] Hongshuang X, Zhonghai Y, Huiling S. Monetary policy,accounting information comparability and adjustment of financing structure [J]. Contemporary Accounting Review, 2017,10(2): 111-131.

[38] Zhenchao Y, Pingui R. Accounting information comparability and investment efficiency [J]. Accounting Research, 2018(6): 39-46.

[39] Peng W, Xiangyu C. Standards convergence, comparability and the optimistic bias of management earnings forecast [J]. Journal of Zhongnan University of Economics and Law, 2017(5): 13-22+158-9.

[40] Donghua Z, Xiaokang Y. Does insider trading affect accounting comparability? [J]. Accounting Research, 2018(3): 27-33.

[41] Xianzhi Z, Kunpeng L, Qinghua L. Deviance from conventional strategy, internal control quality and financial statement comparability [J]. Journal of Audit and Economics, 2018,33(6): 35-47.

[42] Guohui C, Jian Y. Ceo tenure and accounting information comparability [J]. Research on Financial and Economic Issues, 2018(11): 82-89

[43] Guohui C, Jian Y. Cfo's working experience and accounting information comparability — an empirical analysis based on the upper echelons theory [J]. Journal of Shanxi University of Finance and Economics, 2018,40(12): 106-120.

[44] Beasley M S. An empirical analysis of the relation between the board of director composition and financial statement fraud [J]. Accounting Review, 1996,71(4): 443-465.

[45] Dechow P M, Sloan R G, Sweeney A P. Causes and consequences of earnings manipulation: An analysis of firms subject to enforcement actions by the sec [J]. Contemporary Accounting Research, 1996,13

[46] Srinivasan S. Consequences of financial reporting failure for outside directors: Evidence from accounting restatements and audit committee members [J]. Journal of Accounting Research, 2005,43(2): 291-334.

[47] Fama E F. Agency problems and the theory of the firm [J]. Journal of Political Economy, 1980,88(2): 288-307.

[48] Fama E F, Jensen M C. Separation of ownership and control [J]. Journal of Law \& Economics, 1983,26(2): 301-325.

[49] Guoquan C, Rui S. Research on individual learning and behavior modification from perspective of organization management [J]. Science of Science and Management of S\& T, 2013,34(1): 123-134.

[50] Hillman A J, Dalziel T. Boards of directors and firm performance: Integrating agency and resource dependence perspectives [J]. Academy of Management Review, 2003,28(3): 383-396.

[51] Yunsen C, Dengjin Z. ,huang jianqiao.Does informal information channel affect corporate performance? A perspective from independent directors board network [J]. China Accounting Review, 2018,16(1): 27-52.

[52] Peasnell K V, Pope R F, Young S. Board monitoring and earnings management: Do outside directors influence abnormal accruals? [J]. Journal of Business Finance \& Accounting, 2005,32(7-8): 1311-1346.

[53] Faleye O, Hoitash R, Hoitash U. The costs of intense board monitoring [J]. Journal of Financial Economics, 2011,101(1): 160-181.

[54] Basu S. The conservatism principle and the asymmetric timeliness of earnings [J]. Journal of Accounting and Economics, 1997,24(1): 3-37.

[55] Hongxing F, Yong Z, Ping W. Legal environment, supply chain concentration and firm's accounting information comparability [J]. Accounting Research, 2017(7): 33-40+96. 